\title{
PENENTUAN FAKTOR-FAKTOR POTENSIAL YANG MEMPENGARUHI KEJADIAN MALARIA DI PROVINSI PAPUA DENGAN EPIDEMIOLOGI SPASIAL*
}

\author{
Siswanto ${ }^{1 \ddagger}$ and Sri Astuti Thamrin ${ }^{2}$ \\ 1Departemen Statistika, Universitas Hasanuddin, Indonesia, siswanto@unhas.ac.id \\ 2Departemen Statistika, Universitas Hasanuddin, Indonesia, tuti@unhas.ac.id \\ ‡corresponding author
}

Indonesian Journal of Statistics and Its Applications (eISSN:2599-0802)

Vol 4 No 3 (2020), 498 - 509

Copyright (C) 2020 Siswanto and Sri Astuti Thamrin. This is an open-access article distributed under the Creative Commons Attribution License, which permits unrestricted use, distribution, and reproduction in any medium, provided the original work is properly cited.

\begin{abstract}
In Indonesia malaria is found to be widespread in all islands with varying degrees and severity of infection. Based on the Annual of Parasite Incidence (API) in Eastern Indonesia, Malaria is a disease that has a high incidence rate. The three provinces with the highest APIs are Papua (42.64\%), West Papua (38.44\%) and East Nusa Tenggara (16.37\%). Spatial aspects are considered important to be studied because the spread of disease through mosquitoes is strongly influenced by fluctuating climate. The purpose of this study is to determine the potential factors that influence the incidence of Malaria disease in the province of Papua in 2013 by looking at aspects that are the focus of attention in spatial epidemiology. The methods used in analyzing the area are Simultaneous Autoregressive (SAR) and Conditional Autoregressive (CAR) models with a spatial weighting matrix up to second order. The best CAR model is second order through first order compared to other order SAR and CAR models in determining the potential factors affecting the incidence of malaria in Papua Province. The result shows the average monthly wind velocity, average monthly rainfall, and malaria treatment with government program drugs by getting ACT drugs are substantial factors in determining the incidence number of Malaria in Papua based on the lowest AIC value for the secondorder of CAR model. While the SAR model, in this case, has no spatial influence.
\end{abstract}

Keywords: conditional autoregressive, epidemiology, malaria, simultaneous autoregressive, spatial.

\footnotetext{
* Received Jun 2020; Accepted Nov 2020; Published online on Nov 2020
} 


\section{Pendahuluan}

Malaria merupakan suatu penyakit infeksi akut yang disebabkan oleh infeksi Plasmodium yang menyerang sel darah merah (Febriyanti \& Suwadi, 2019). Plasmodium yang terbawa melalui gigitan nyamuk akan berkembang biak di dalam sel darah merah manusia. Penyakit malaria menyerang hampir semua kelompok umur baik perempuan maupun laki-laki. Orang yang terkena malaria ditandai dengan dengan gejala anemia, demam, menggigil, dan pembesaran limpa (Arsin, 2012).

Malaria merupakan masalah yang sifatnya sudah global hal tersebut berdasarkan pada konferensi menteri kesehatan dunia. World Malaria Report 2015 menyebutkan bahwa negara dengan iklim tropis dan subtropis menjadi wilayah endemis malaria. Negara Asia Tenggara yang termasuk wilayah endemis malaria yaitu Indonesia, Myanmar, dan Thailand. Berdasarkan komitmen global Millenium Development Goals (MDGs), Pemberantasan malaria masuk ke dalam salah satu tujuan yang harus dicapai sampai tahun 2015 (Arsin, 2012). Berakhirnya MDGs pada tahun 2015, kemudian dilanjutkan melalui Sustainable Development Goals (SDGs). Dalam tujuan ketiga SDGs, yaitu menjamin kehidupan yang sehat dan mengupayakan kesejahteraan bagi semua orang, dengan tujuan yang spesifik yaitu pemberantasan dan mengakhiri AIDS, tuberkulosis, dan malaria sampai dengan tahun 2030 .

Penyakit yang ditularkan melalui gigitan nyamuk Anopheles betina masih menjadi masalah kesehatan di beberapa wilayah Indonesia. Berdasarkan API (Annual Parasite Incidence), Indonesia bagian timur masuk dalam stratifikasi malaria yang tinggi. Tiga provinsi di wilayah timur Indonesia dengan nilai API tertinggi yaitu Provinsi Papua (42.64\%), Provinsi Papua Barat (38.44\%) dan Provinsi Nusa Tenggara Timur (16.37\%) ([KEMENKES RI], 2014). Kejadian atau penularan penyakit malaria disebabkan oleh faktor-faktor yang biasa disebut dengan agent (parasit plasmodium), environment (lingkungan fisik, kimiawi, biologik, sosial) dan host (manusia dan nyamuk Anopheles) (Arsin, 2012). Berdasarkan faktor tersebut, faktor lingkungan fisik dan lingkungan sosial menjadi fokus utama dari peneliti. Selain beberapa faktor tersebut, salah satu faktor yang mempengaruhi penyebaran penyakit malaria adalah kondisi geografis suatu wilayah, sehingga analisis spasial sangat penting untuk mengatasi masalah ini. Pada data spasial seringkali observasi di suatu wilayah bergantung pada observasi di lokasi yang saling berdekatan (Siswanto et al., 2017).

Aspek spasial dinilai penting untuk dikaji karena penyebaran penyakit melalui nyamuk yang sangat dipengaruhi oleh iklim yang fluktuatif. Aspek yang penting dalam spasial epidemiologi adalah faktor-faktor potensial yang memberikan pengaruh pada kejadian penyakit di suatu wilayah (Waller, 2005). Model yang sering digunakan dalam menganalisis area terutama dalam bidang epidemiologi adalah model Simultaneous Autoregressive (SAR) dan Conditional Autoregressive (CAR) (De Oliveira, 2012). Model SAR merupakan model spasial autoregresif yang mengamati variabel acak pada suatu lokasi secara bersamaan, sedangkan model spasial autoregresif CAR merupakan model yang mengamati variabel acak pada setiap wilayah bersyarat tertentu di wilayah tetangganya (Wall, 2004). Kedekatan geografis belum dapat ditransformasikan menjadi ketergantungan spasial antar Kabupaten/Kota, bahkan wilayah yang dipisahkan oleh satu wilayah lainnya dapat memberikan pengaruh (Siswanto et al., 2017). 
Oleh karena itu, dalam studi ini akan dianalisis faktor-faktor potensial yang mempengaruhi kejadian malaria di Provinsi Papua menggunakan epidemiologi spasial. Dalam hal ini akan dibandingkan model SAR dan CAR dengan matriks pembobot spasial sampai orde dua.

\section{Materi dan Metode}

\subsection{Area Studi}

Papua merupakan provinsi terluas dan terletak dibagian paling timur wilayah Indonesia. Sejak tahun 2003 wilayah Provinsi Papua dibagi menjadi dua bagian yaitu Provinsi Papua dan Papua Barat. Provinsi Papua dengan ibukota Jayapura, memiliki luas $316553.07 \mathrm{~km}^{2}$ atau 16.70 persen dari luas Indonesia.

Indonesia yang merupakan negara dengan iklim tropis yang hanya dipengaruhi oleh musim hujan dan musim kemarau, karena pengaruh iklim di suatu wilayah dapat menyebabkan berbagai macam penyakit. Kejadian suatu penyakit yang menular disebabkan oleh faktor-faktor yang disebut dengan agent, environment, dan host. Epidemiologi dari penyakit malaria, memiliki hubungan yang saling berkaitan antara, agent, environment, dan host pada penularan penyakit malaria (Arsin, 2012).

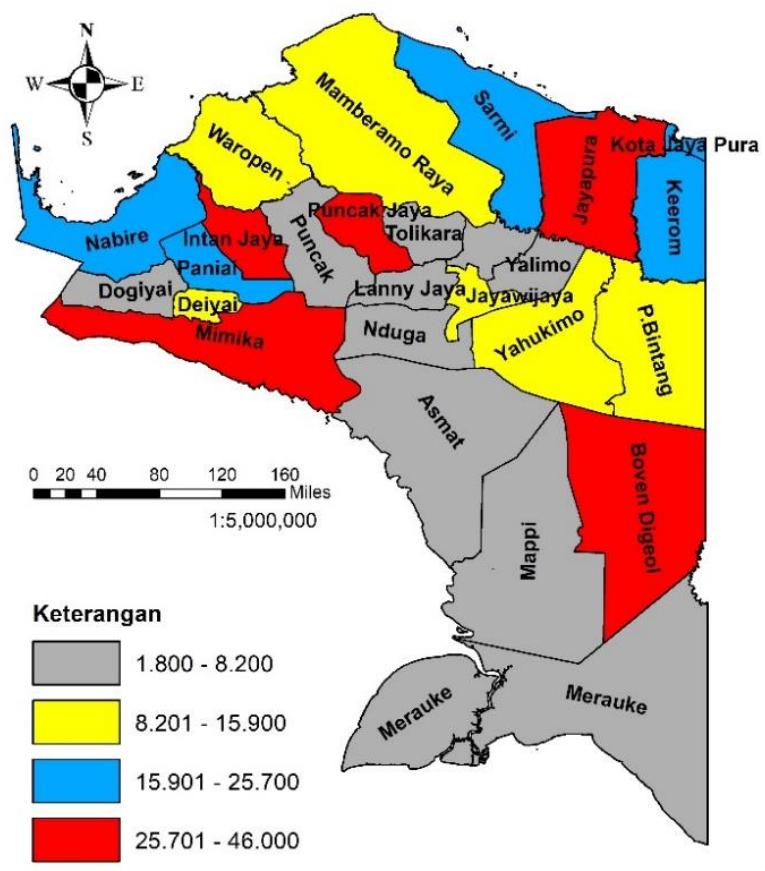

Gambar 1: Penyebaran persentase penderita malaria di Provinsi Papua

Kondisi geografi dan metereologi di Indonesia, serta kebiasaan masyarakat sangat memungkinkan untuk penyebaran penyakit malaria, terutama di Provinsi Papua yang menjadi salah satu wilayah endemis malaria di Indonesia, dengan jumlah API mencapai $42.64 \%$ pada tahun 2013. Gambar 1 menunjukkan kabupaten dengan persentase penderita malaria tinggi terjadi di Kabupaten Intan Jaya, Mimika, Puncak, Jayapura dan Boven Digoel hal ini ditandai dengan warna merah pada peta. 
Kabupaten dengan jumlah penderita malaria yang rendah adalah Kabupaten Nduga, Dogiyai, Puncak, Tolikara, Mamberamo Tengah, Yalimo, Lanny Jaya, Asmat, Mappi dan Merauke yang ditandai dengan warna abu-abu pada peta.

\subsection{Sumber Data}

Data yang digunakan dalam penelitian ini adalah data hasil publikasi oleh Kementerian Kesehatan Republik Indonesia dengan judul Riset Kesehatan Dasar Dalam Angka Provinsi Papua tahun 2013 ([KEMENKES RI], 2013) dan Badan Pusat Statistik Provinsi Papua tahun 2013 ([BPS], 2014). Variabel respon dan variabel penjelas yang digunakan dapat dilihat pada Tabel 1.

Tabel 1: Variabel respon dan penjelas

\begin{tabular}{clc}
\hline Variabel & \multicolumn{1}{c}{ Nama Variabel } & Satuan \\
\hline $\mathrm{Y}$ & Penderita Penyakit Malaria & $\%$ \\
$\mathrm{X}_{1}$ & Rata-rata suhu udara bulanan & ${ }^{\circ} \mathrm{C}$ \\
$\mathrm{X}_{2}$ & Rata-rata kelembaban udara bulanan & $\%$ \\
$\mathrm{X}_{3}$ & Rata-rata kecepatan angin bulanan & $\mathrm{knot}$ \\
$\mathrm{X}_{4}$ & Rata-rata curah hujan bulanan & $\mathrm{mm}$ \\
$\mathrm{X}_{5}$ & Rumah tangga yang menggunakan kelambu & $\%$ \\
$\mathrm{X}_{6}$ & Rumah tangga yang menggunakan obat nyamuk bakar & $\%$ \\
$\mathrm{X}_{7}$ & Rumah tangga yang menggunakan kassa nyamuk & $\%$ \\
$\mathrm{X}_{8}$ & Rumah tangga dalam perilaku pencegahan gigitan & $\%$ \\
& nyamuk dengan menggunakan Repelan & \\
$\mathrm{X}_{9}$ & Pengobatan malaria dengan obat program dengan & $\%$ \\
& mendapatkan obat ACT & \\
\hline
\end{tabular}

\subsection{Formulasi Model}

\subsubsection{Matriks Pembobot Spasial}

Dalam analisis spasial salah satu matriks yang penting adalah matriks pembobot spasial. Matriks tersebut menggambarkan hubungan antar wilayah yang diperoleh berdasarkan informasi jarak atau ketetanggan. Dalam penelitian ini matriks pembobot spasial yang digunakan adalah ketetanggaan yaitu queen contiguity, yaitu wilayah pengamatannya ditentukan berdasarkan sisi dan sudut yang saling bersinggungan dengan nilai 0 yang tidak termasuk tetangga atau 1 yang termasuk tetangga, menggambarkan struktur tetangga orde satu dan dua untuk masing-masing unit. Apabila terdapat dua wilayah yang saling berdekatan, akan tetapi diantaranya ada satu wilayah lain, wilayah tersebut dinyatakan memiliki ketetanggaan spasial orde dua.

i. Misalkan akan dibuat matriks pembobot spasial yang disimbolkan dengan $W$ untuk Gambar 1. 


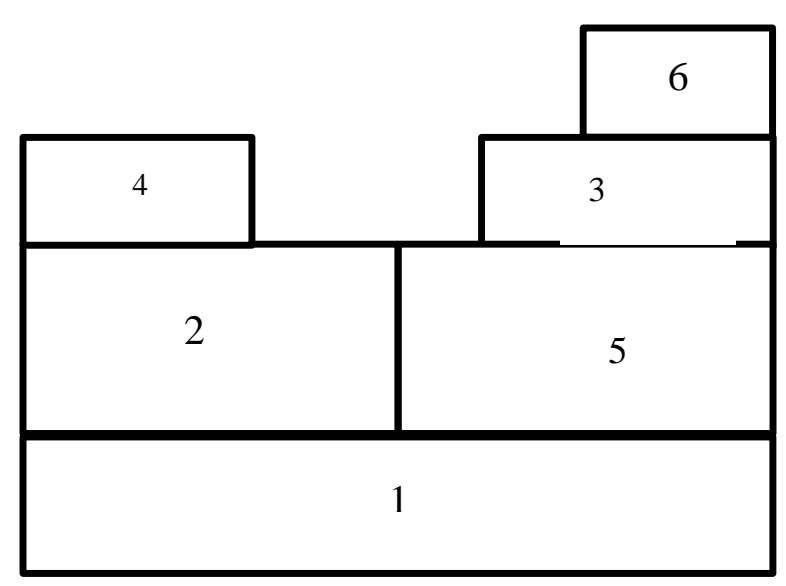

Gambar 2: Ilustrasi ketetanggaan spasial

Untuk orde satu, dari Gambar 2 wilayah yang dinyatakan saling ketetanggaan spasial orde satu adalah:

- Wilayah 1 bertetangga dengan wilayah 2 dan 5

- Wilayah 2 bertetangga dengan wilayah 1, 4 dan 5

- Wilayah 3 bertetangga dengan wilayah 5 dan 6

- Wilayah 4 bertetangga dengan wilayah 2

- Wilayah 5 bertetangga dengan wilayah 1,2 dan 3

- Wilayah 6 bertetangga dengan wilayah 3

Elemen matriks akan bernilai 1 jika wilayah ke- $i$ bertetangga dengan wilayah $\mathrm{ke}-j$ dan bernilai 0 jika wilayah $\mathrm{ke}-i$ tidak berdekatan dengan wilayah ke $-j$. Sesuai dengan peta wilayah Gambar 2, diperoleh $W^{*}$ dengan metode queen contiguity sebagai berikut:

$$
\mathrm{W}^{*}=\left[\begin{array}{llllll}
0 & 1 & 0 & 0 & 1 & 0 \\
1 & 0 & 0 & 1 & 1 & 0 \\
0 & 0 & 0 & 0 & 1 & 1 \\
0 & 1 & 0 & 0 & 0 & 0 \\
1 & 1 & 1 & 0 & 0 & 0 \\
0 & 0 & 1 & 0 & 0 & 0
\end{array}\right]
$$

ii. Untuk orde dua, apabila terdapat dua wilayah yang saling bertetangga, akan tetapi diantaranya terdapat satu wilayah lain yang memisahkan, keduanya dinyatakan memiliki ketetanggaan spasial orde dua. wilayah yang dinyatakan memiliki ketetanggaan spasial orde dua adalah:

- Wilayah 1 bertetangga dengan wilayah 3 dan 4

- Wilayah 2 bertetangga dengan wilayah 3

- Wilayah 3 bertetangga dengan wilayah 1 dan 2

- Wilayah 4 bertetangga dengan wilayah 1 dan 5

- Wilayah 5 bertetangga dengan wilayah 4 dan 6

- Wilayah 6 bertetangga dengan wilayah 5 
Elemen matriks akan benilai 1 jika wilayah $k e-i$ berdekatan walaupun diantaranya terdapat satu wilayah lain, maka keduanya dinyatakan sebagai ketetanggaan spasial orde 2 dengan wilayah ke-j. Sesuai dengan peta wilayah Gambar 2, diperoleh $W^{*}$ dengan metode queen contiguity sebagai berikut:

$$
\mathrm{W}^{*}=\left[\begin{array}{llllll}
0 & 0 & 1 & 1 & 0 & 0 \\
0 & 0 & 1 & 0 & 0 & 0 \\
1 & 1 & 0 & 0 & 0 & 0 \\
1 & 0 & 0 & 0 & 1 & 0 \\
0 & 0 & 0 & 1 & 0 & 1 \\
0 & 0 & 0 & 0 & 1 & 0
\end{array}\right]
$$

\subsubsection{Model SAR}

Model SAR merupakan model autoregresif yang mengamati variabel acak pada satu wilayah dengan wilayah lainnya secara simultan atau bersama. Misal $\left\{z_{\left(S_{i}\right)}: S_{i} \in\left(S_{1}, \ldots, S_{n}\right)\right\}$ merupakan suatu proses Gaussian acak dengan $\left(S_{1}, \ldots, S_{n}\right)$ bentuk area D. $D=S_{1} \cup S_{2} \cup \ldots \cup S_{n}$ dan $S_{i} \cap S_{j}=0 ; \forall i \neq j$ sehingga persamaan model SAR dapat dituliskan sebagai berikut:

$$
z_{\left(s_{i}\right)}=\boldsymbol{X} \boldsymbol{\beta}+\rho \sum_{j=1}^{n} w_{i j}\left(z_{\left(s_{j}\right)}-\boldsymbol{X} \boldsymbol{\beta}\right)+\varepsilon_{i}, i=1, \ldots, n
$$

dengan $\varepsilon$ menyebar normal ganda dengan rata-rata adalah $\mathbf{0}$ dan matriks ragam peragam $\boldsymbol{\Lambda}\left(\boldsymbol{\Lambda}=\boldsymbol{\sigma}^{2} \boldsymbol{I}\right)$ dengan $\boldsymbol{I}$ merupakan suatu matriks identitas.

Model SAR dapat dituliskan dalam bentuk matriks sebagai berikut:

$$
\boldsymbol{z}=\boldsymbol{X} \boldsymbol{\beta}+\rho \boldsymbol{W}(\boldsymbol{z}-\boldsymbol{X} \boldsymbol{\beta})+\boldsymbol{\varepsilon}
$$

dengan $\mathbf{z}=\left(z_{\left(s_{1}\right)}, \ldots, z_{\left(s_{n}\right)}\right)$ dan $(\boldsymbol{I}-\boldsymbol{B})(\boldsymbol{z}-\boldsymbol{X} \boldsymbol{\beta})=\varepsilon$ dengan $E(\boldsymbol{X} \boldsymbol{\beta})$ dan $\operatorname{Var}(\mathbf{z})=$ $(\boldsymbol{I}-\boldsymbol{B})^{-\mathbf{1}} \boldsymbol{\Lambda}\left(\boldsymbol{I}-\boldsymbol{B}^{\prime}\right)^{-\mathbf{1}}$ sehingga $z \sim N\left(\boldsymbol{\mu},(\boldsymbol{I}-\boldsymbol{B})^{-\mathbf{1}} \boldsymbol{\Lambda}\left(\boldsymbol{I}-\boldsymbol{B}^{\prime}\right)^{-\mathbf{1}}\right)$ (Cressie 1990).

\subsubsection{Model CAR}

Model CAR merupakan suatu model autoregresif bersyarat yang mengamati peubah acak pada satu wilayah apabila wilayah yang lain telah diketahui (Wall, 2004). Jika Z menyebar normal maka fungsi peluang bersyaratnya adalah:

$$
f\left(\mathrm{Z}\left(\mathrm{s}_{\mathrm{i}}\right) \mid\left\{\mathrm{Z}\left(\mathrm{s}_{\mathrm{j}}\right): j \neq i\right\}\right)=\left(2 \pi \sigma_{i}^{2}\right)^{-\frac{1}{2}} \exp -\frac{1}{2 \sigma_{i}^{2}}\left[\left\{\mathrm{Z}\left(\mathrm{s}_{\mathrm{i}}\right)-\theta_{i}\left(\left\{\mathrm{Z}\left(\mathrm{s}_{\mathrm{j}}\right): j \neq i\right\}\right)\right\}^{2}\right]
$$

untuk $i=1, \ldots, n$ dengan $f$ adalah fungsi peluang bersyarat dari $\mathrm{Z}\left(s_{i}\right) \mid\left\{\mathrm{Z}\left(s_{j}\right)=\right.$ $\left.\mathrm{z}\left(s_{j}\right) ; j=1, \ldots, n ; j \neq i\right\}$. $\theta_{i}$ dan $\sigma_{i}^{2}$ masing-masing adalah rataan dan ragam kondisional (Cressie, 1990). Dalam bentuk lain model CAR dapat dituliskan sebagai berikut:

$$
\left(\mathrm{Z}\left(\mathrm{s}_{\mathrm{i}}\right) \mid\left\{\mathrm{Z}\left(\mathrm{s}_{\mathrm{j}}\right): j \neq i\right\}\right)=\mu_{i}+\rho \sum_{j=1}^{n} W_{i j}\left(\mathrm{Z}\left(\mathrm{s}_{\mathrm{j}}\right)-\mu_{j}\right), \mathrm{i}=1, \ldots, \mathrm{n}
$$

dengan $\mu_{i}$ adalah nilai harapan pada $i$, dan $\rho$ adalah parameter otokorelasi spasial yang menentukan ukuran dan sifat (positif atau negatif) dari efek spasial. Penjumlahan dari Persamaan 1 adalah jumlah rata-rata pembobot yang sesuai dari semua lokasi lain yaitu $j$. Apabila dituliskan dalam bentuk matriks diperoleh:

$$
\mathbf{Z}=\boldsymbol{X} \boldsymbol{\beta}+\boldsymbol{B}_{\boldsymbol{\rho}}^{-1} \boldsymbol{\varepsilon} \Rightarrow \mathbf{Z}-\boldsymbol{X} \boldsymbol{\beta}=\boldsymbol{B}_{\boldsymbol{\rho}}^{-1} \boldsymbol{\varepsilon} \text { masing-masing ruas dikali } \boldsymbol{B}_{\boldsymbol{\rho}}
$$




$$
\begin{aligned}
& \Rightarrow \boldsymbol{B}_{\boldsymbol{\rho}}(\mathbf{Z}-\boldsymbol{X} \boldsymbol{\beta})=\boldsymbol{\varepsilon} \\
& \Rightarrow\left(\boldsymbol{I}_{\boldsymbol{n}}-\rho \boldsymbol{W}\right)(\mathbf{Z}-\boldsymbol{X} \boldsymbol{\beta})=\boldsymbol{\varepsilon} \\
& \Rightarrow \mathbf{Z}-\boldsymbol{X} \boldsymbol{\beta}-\rho \boldsymbol{W}(\mathbf{Z}-\boldsymbol{X} \boldsymbol{\beta})=\boldsymbol{\varepsilon} \\
& \Rightarrow \mathbf{Z}=\boldsymbol{X} \boldsymbol{\beta}+\rho \boldsymbol{W}(\mathbf{Z}-\boldsymbol{X} \boldsymbol{\beta})+\boldsymbol{\varepsilon}
\end{aligned}
$$

Matriks korelasi spasial $\mathbf{C}=\mathbf{B}+\mathbf{B}^{\prime}-\mathbf{B B}^{\prime}$ dengan $\mathbf{B}=\rho \mathbf{W}$. Sebaran peluang bersyarat $\mathbf{Z} \sim \mathrm{N}\left(\boldsymbol{\mu},(\mathbf{I}-\mathbf{C})^{-1} \mathbf{M}\right)$. (I - C) memiliki invers dan $(\mathbf{I}-\mathbf{C})^{-1} \mathbf{M}$ merupakan matriks simetris dan definit positif. $\mathbf{Z}=\left(\mathrm{Z}\left(s_{1}\right), \ldots, \mathrm{Z}\left(s_{n}\right)\right)^{\prime}, \boldsymbol{\mu}=\left(\mu_{1}, \ldots, \mu_{n}\right)^{\prime}, \mathbf{C}=\left(c_{i j}\right)$ adalah matriks berukuran $n \times n$ dan $\mathbf{M}=\operatorname{diag}\left(\sigma_{1}^{2}, \ldots, \sigma_{n}^{2}\right)$ adalah matriks diagonal $n \times n$ (Cressie, 1990).

\subsubsection{Pendugaan Korelasi Spasial $(\widehat{\rho})$ pada SAR dan CAR}

Perkalian matriks pembobot $\mathbf{W}$ dan penduga korelasi spasial ( $\hat{\rho}$ ) akan menghasilkan matriks korelasi spasial $\mathbf{B}$.

Fungsi kemungkinan maksimum korelasi spasial adalah:

$l\left(\sigma^{2}, \rho, \boldsymbol{\beta} ; \mathbf{Z}\right)=c(\mathbf{Z})-\frac{n}{2} \ln \sigma^{2}+\ln |\mathbf{I}-\rho \boldsymbol{W}|-\frac{1}{2 \sigma^{2}}[(\mathbf{I}-\rho \boldsymbol{W}) \mathbf{Z}-\boldsymbol{X} \boldsymbol{\beta}]^{T}[(\mathbf{I}-\rho \boldsymbol{W}) \mathbf{Z}-\boldsymbol{X} \boldsymbol{\beta}]$

Fungsi log-likelihood pada $H_{0}$ adalah:

$$
l_{0}\left(\sigma^{2}, \boldsymbol{\beta} ; \mathbf{Z}\right)=c(\mathbf{Z})-\frac{n}{2} \ln \sigma^{2}-\frac{1}{2 \sigma^{2}}[\mathbf{Z}-\boldsymbol{X} \boldsymbol{\beta}]^{T}[\mathbf{Z}-\boldsymbol{X} \boldsymbol{\beta}]
$$

Uji independensi spasial dapat diturunkan dengan Statistik uji Nisbah kemungkinan yang merupakan selisih dari Persamaan 2 dan Persamaan 3 , sehingga

$$
\begin{aligned}
L R T=-2\left[l\left(\sigma^{2}, \rho, \boldsymbol{\beta} ; \mathbf{Z}\right)-l_{0}\left(\sigma^{2}, \boldsymbol{\beta} ; \mathbf{Z}\right)\right] \\
\begin{aligned}
&=-2\{c(\mathbf{Z})- \frac{n}{2} \ln \sigma^{2}+\ln |\mathbf{I}-\rho \boldsymbol{W}|-\frac{1}{2 \sigma^{2}}[(\mathbf{I}-\rho \boldsymbol{W}) \mathbf{Z}-\boldsymbol{X} \boldsymbol{\beta}]^{T}[(\mathbf{I}-\rho \boldsymbol{W}) \mathbf{Z}-\boldsymbol{X} \boldsymbol{\beta}] \\
&\left.\quad-\left(c(\mathbf{Z})-\frac{n}{2} \ln \sigma^{2}-\frac{1}{2 \sigma^{2}}[\mathbf{Z}-\boldsymbol{X} \boldsymbol{\beta}]^{T}[\mathbf{Z}-\boldsymbol{X} \boldsymbol{\beta}]\right)\right\} \\
&=-2\left\{c(\mathbf{Z})-\frac{n}{2} \ln \sigma^{2}+\ln |\mathbf{I}-\rho \boldsymbol{W}|-\frac{1}{2 \sigma^{2}}[(\mathbf{I}-\rho \boldsymbol{W}) \mathbf{Z}-\boldsymbol{X} \boldsymbol{\beta}]^{T}[(\mathbf{I}-\rho \boldsymbol{W}) \mathbf{Z}-\boldsymbol{X} \boldsymbol{\beta}]\right. \\
&\left.+c(\mathbf{Z})+\frac{n}{2} \ln \sigma^{2}+\frac{1}{2 \sigma^{2}}[\mathbf{Z}-\boldsymbol{X} \boldsymbol{\beta}]^{T}[\mathbf{Z}-\boldsymbol{X} \boldsymbol{\beta}]\right\} \\
&=-2\left\{-\frac{n}{2} \ln \sigma^{2}+\ln |\mathbf{I}-\rho \boldsymbol{W}|-\frac{1}{2 \sigma^{2}}[(\mathbf{I}-\rho \boldsymbol{W}) \mathbf{Z}-\boldsymbol{X} \boldsymbol{\beta}]^{T}[(\mathbf{I}-\rho \boldsymbol{W}) \mathbf{Z}-\boldsymbol{X} \boldsymbol{\beta}]\right. \\
&\left.\quad+\frac{n}{2} \ln \sigma^{2}+\frac{1}{2 \sigma^{2}}[\mathbf{Z}-\boldsymbol{X} \boldsymbol{\beta}]^{T}[\mathbf{Z}-\boldsymbol{X} \boldsymbol{\beta}]\right\}
\end{aligned} \\
L R T=\left\{-2 \ln |\mathbf{I}-\rho \boldsymbol{W}|+\frac{1}{\sigma^{2}}[(\mathbf{I}-\rho \boldsymbol{W}) \mathbf{Z}-\boldsymbol{X} \boldsymbol{\beta}]^{T}[(\mathbf{I}-\rho \boldsymbol{W}) \mathbf{Z}-\boldsymbol{X} \boldsymbol{\beta}]-\frac{1}{\sigma^{2}}[\mathbf{Z}-\right. \\
\left.\boldsymbol{X} \boldsymbol{\beta}]^{T}[\mathbf{Z}-\boldsymbol{X} \boldsymbol{\beta}]\right\}
\end{aligned}
$$

Apabila Persamaan 4 diturunkan terhadap $\rho$ diperoleh penduga korelasi spasial $(\hat{\rho})$ yaitu:

$$
\hat{\rho}=\left(\mathbf{Z}^{\mathrm{T}} \boldsymbol{W}^{T} \boldsymbol{W} \mathbf{Z}\right)^{-1} \mathbf{Z}^{\mathrm{T}} \boldsymbol{W}^{T} \mathbf{Z}
$$

Pengujian nilai signifikansi dari koefisien korelasi spasial $(\hat{\rho})$ menggunakan uji nisbah kemungkinan. Pengujian hipotesisnya adalah:

$H_{0}: \rho=0$ (Tidak terdapat korelasi spasial)

$H_{1}: \rho \neq 0$ (Ada korelasi spasial)

Kesimpulan dari hipotesis tersebut yaitu $H_{0}$ akan ditolak jika nilai $L R T>\chi_{(1)}^{2}$ 


\section{Hasil dan Pembahasan}

\subsection{Eksplorasi Data}

Eksplorasi data berguna untuk mempelajari karakteristik data agar lebih mudah dalam menentukan model analisis statistik yang sesuai. Selanjutnya yang perlu dilakukan adalah memerhatikan hubungan antar variabel penjelas dan variabel respon dapat dilihat dari Gambar 3 korelasi yang dihasilkan.

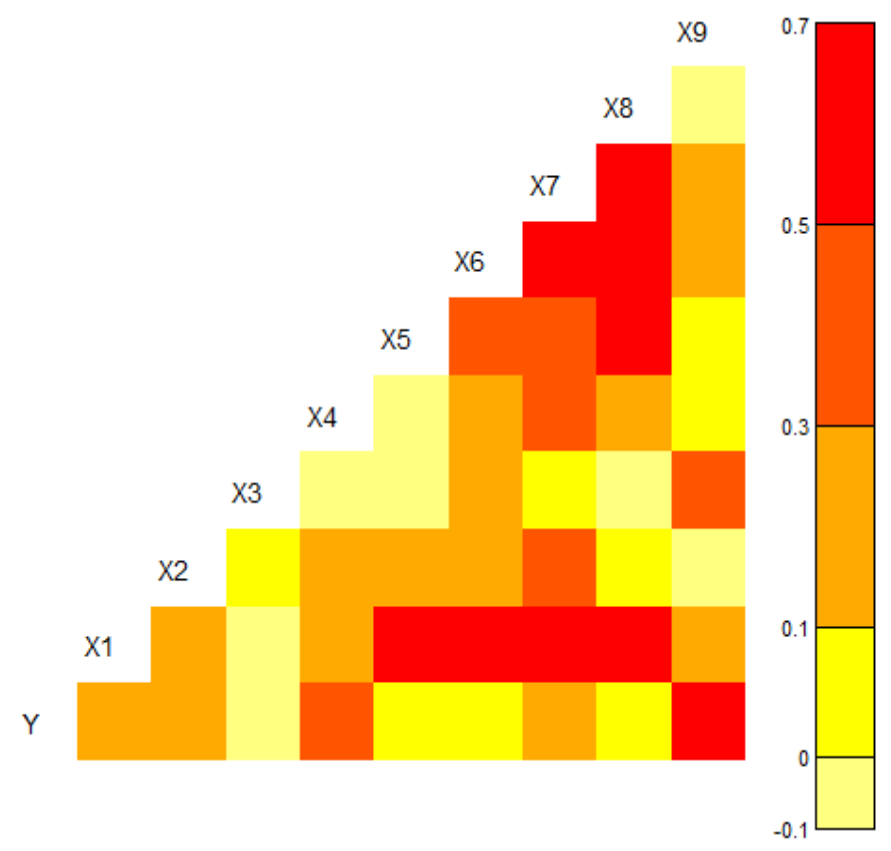

Gambar 3: Korelasi antar variabel

Gambar 3 menginformasikan bahwa beberapa variabel penjelas memiliki nilai koefisien korelasi yang tinggi dengan variabel penjelas lainnya yaitu variabel $X_{1}$ dengan variabel $X_{5}, X_{6}, X_{7}$, dan $X_{8}$ kemudian variabel $X_{5}$ dengan variabel $X_{8}$, variabel $X_{6}$ dengan variabel $X_{7}$ dan $X_{8}$, serta variabel $X_{7}$ dengan variabel $X_{8}$, dengan rentang nilai koefisien korelasi yang dihasilkan adalah $0.5-0.7$. Variabel $X_{3}$ memiliki korelasi negatif dengan variabel respon.

Adanya nilai koefisien korelasi yang tinggi antar variabel bebas mengakibatkan tidak terpenuhinya asumsi multikolinieritas, untuk mengatasi kasus multikolinieritas dilakukan penyeleksian variabel dengan menggunakan metode stepwise. Hasil dari penyeleksian variabel dengan metode stepwise diperoleh dari sembilan variabel yang digunakan terdapat tiga variabel yang signifikan yaitu rata-rata kecepatan angin $\left(X_{3}\right)$, rata-rata curah hujan bulanan $\left(\mathrm{X}_{4}\right)$, dan proporsi rumah tangga yang mendapatkan obat ACT $\left(X_{9}\right)$. 


\subsection{Analisis Model SAR}

Analisis model SAR dengan matriks pembobot orde satu pada Provinsi Papua dengan melibatkan wilayah administratif tanpa wilayah kepulauan menggunakan uji LRT diperoleh nilai $L R T=0.338$ dengan korelasi spasial $\hat{\rho}=0.039$ dan nilai- $p=0.561$. Berarti bahwa model tersebut tidak nyata pada $\alpha=0.05$ yang mengindikasikan tidak terdapat hubungan spasial. Untuk matriks pembobot orde dua pada Provinsi Papua dengan melibatkan wilayah administratif tanpa wilayah kepulauan menggunakan uji LRT diperoleh nilai $L R T=0.935$ dengan korelasi spasial $\hat{\rho}=0.061$ dan nilai- $p=0.333$. Berarti bahwa model tersebut tidak nyata pada $\alpha=0.05$ yang mengindikasikan tidak terdapat hubungan spasial. Untuk model SAR dengan matriks pembobot orde dua melalui orde satu diperoleh nilai $\mathrm{LRT}=0.013$ dengan nilai korelasi spasial $\hat{\rho}=-0.008$ dan nilai-p $=0.909$. Berarti bahwa model tersebut tidak nyata pada $\alpha=0.05$ yang mengindikasikan tidak terdapat hubungan spasial. Hasil pendugaan model SAR dari ketiga matriks pembobot yang digunakan, walaupun dengan menggunakan model SAR pengaruh spasial atau wilayah tidak terlalu berpengaruh untuk kasus penularan penyakit malaria di Papua, hasil tersebut dapat dilihat pada Tabel 2.

Tabel 2: Analisis perbandingan SAR untuk data kejadian malaria di Provinsi Papua tahun 2013

\begin{tabular}{clllll}
\hline Orde & & Intersep & $\mathrm{X}_{3}$ & $\mathrm{X}_{4}$ & $\mathrm{X}_{9}$ \\
\hline Orde satu & Koefisien & -4.846 & -0.729 & 0.044 & 0.335 \\
& Galat baku & 6.317 & 0.342 & 0.018 & 0.068 \\
& Nilai-p & 0.443 & 0.032 & 0.017 & 0.000 \\
\hline Orde dua & Koefisien & -2.996 & -0.506 & 0.038 & 0.316 \\
& Galat baku & 6.317 & 0.342 & 0.018 & 0.068 \\
& Nilai-p & 0.635 & 0.139 & 0.036 & 0.000 \\
\hline Orde dua melalui satu & Koefisien & 16.622 & -0.0009 & 0.0001 & -0.0031 \\
& Galat baku & 0.085 & 0.004 & 0.0002 & 0.0009 \\
& Nilai-p & 0.000 & 0.847 & 0.452 & 0.001 \\
\hline
\end{tabular}

\subsection{Analisis Model CAR}

Analisis model CAR dengan matriks pembobot orde satu pada Provinsi Papua dengan melibatkan wilayah administratif tanpa wilayah kepulauan menggunakan uji LRT diperoleh nilai $L R T=457.520$, nilai korelasi spasial $\hat{\rho}=0.740$ dengan nilai- $p=0.000$. Berarti bahwa model tersebut nyata pada $\alpha=0.05$ yang mengindikasikan terdapat hubungan spasial. Untuk model CAR dengan matriks pembobot orde dua pada Provinsi Papua dengan melibatkan wilayah administratif tanpa wilayah kepulauan menggunakan uji LRT diperoleh nilai LRT $=427.050$, nilai korelasi spasial $\hat{\rho}=0.549$ dengan nilai- $p=0.000$. Berarti bahwa model tersebut nyata pada $\alpha=0.05$ yang mengindikasikan terdapat hubungan spasial. model CAR orde dua melalui orde satu pada Provinsi Papua dengan melibatkan wilayah administratif tanpa wilayah kepulauan menggunakan uji LRT diperoleh nilai $L R T=435.680$, nilai korelasi spasial 
$\hat{\rho}=0.480$ dengan nilai- $p=0.000$. Berarti bahwa model tersebut nyata pada $\alpha=0.05$ yang mengindikasikan terdapat hubungan spasial.

Uji signifikansi variabel pada Tabel 3 diperoleh informasi, semua variabel yang dimasukkan ke dalam model signifikan yaitu $\mathrm{X}_{3}, \mathrm{X}_{4}$, dan $\mathrm{X}_{9}$ baik itu orde satu, orde dua, maupun orde dua melalui orde satu. Untuk orde satu memiliki makna bahwa setiap kenaikan nilai rata-rata kecepatan angin $\left(X_{3}\right)$ di suatu wilayah dengan tetangga orde satu yang bergantung pada nilai-nilai dari tetangganya, sebesar satu satuan akan menyebabkan persentase penderita penyakit malaria di wilayah tersebut naik sebesar 0.856 persen. Kenaikan nilai rata-rata curah hujan $\left(X_{4}\right)$ di suatu wilayah dengan tetangga orde satu yang bergantung pada nilai-nilai dari tetangganya, sebesar satu satuan akan menyebabkan persentase penderita penyakit malaria di wilayah tersebut naik sebesar 0.026 persen. Kenaikan nilai rata-rata $\left(X_{9}\right)$ di suatu wilayah dengan tetangga orde satu yang bergantung pada nilai-nilai dari tetangganya, sebesar sebesar satu satuan akan menyebabkan persentase penderita penyakit malaria di wilayah tersebut naik sebesar 0.177 persen.

Matriks pembobot orde dua memiliki makna bahwa setiap kenaikan nilai rata-rata kecepatan angin $\left(X_{3}\right)$ di suatu wilayah dengan tetangga orde dua, tanpa melihat pengaruh dari tetangga langsung yang bergantung pada nilai-nilai dari tetangganya, sebesar satu satuan akan menyebabkan persentase penderita penyakit malaria di wilayah tersebut naik sebesar 2.837 persen. Kenaikan nilai rata-rata curah hujan $\left(\mathrm{X}_{4}\right)$ di suatu wilayah dengan tetangga orde dua, tanpa melihat pengaruh dari tetangga langsung yang bergantung pada nilai-nilai dari tetangganya, sebesar satu satuan akan menyebabkan persentase penderita penyakit malaria di wilayah tersebut naik sebesar 0.256 persen. Kenaikan nilai rata-rata $\left(X_{9}\right)$ di suatu wilayah dengan tetangga orde dua, tanpa melihat pengaruh dari tetangga langsung yang bergantung pada nilai-nilai dari tetangganya sebesar satu satuan akan menyebabkan persentase penderita penyakit malaria di wilayah tersebut naik sebesar 1.289 persen.

Matriks pembobot orde dua melalui orde satu. Kenaikan nilai rata-rata kecepatan angin $\left(X_{3}\right)$ di suatu wilayah dengan tetangga orde dua, dengan melihat pengaruh dari tetangga langsung yang bergantung pada nilai-nilai dari tetangganya, sebesar satu satuan akan menyebabkan persentase penderita penyakit malaria di wilayah tersebut turun sebesar 0.012 persen. Kenaikan nilai rata-rata curah hujan $\left(\mathrm{X}_{4}\right)$ di suatu wilayah dengan tetangga orde dua, dengan melihat pengaruh dari tetangga langsung yang bergantung pada nilai-nilai dari tetangganya, sebesar satu satuan akan menyebabkan persentase penyakit malaria di wilayah tersebut naik sebesar 0.0002 persen. Kenaikan nilai rata-rata $\left(X_{9}\right)$ di suatu wilayah dengan tetangga orde dua, dengan melihat pengaruh dari tetangga langsung yang bergantung pada nilai-nilai dari tetangganya, sebesar satu satuan akan menyebabkan persentase penderita penyakit malaria di wilayah tersebut turun sebesar 0.002 persen. 
Tabel 3: Analisis perbandingan CAR untuk data kejadian malaria di Provinsi Papua tahun 2013

\begin{tabular}{clllll}
\hline \multicolumn{1}{c}{ Orde } & & Intersep & $\mathrm{X}_{3}$ & $\mathrm{X}_{4}$ & $\mathrm{X}_{9}$ \\
\hline Orde satu & Koefisien & -3.522 & 0.856 & 0.026 & 0.177 \\
& Galat baku & $9.61 \times 10^{-4}$ & $7.29 \times 10^{-5}$ & $3.18 \times 10^{-6}$ & $1.38 \times 10^{-5}$ \\
& Nilai-p & 0.000 & 0.000 & 0.000 & 0.000 \\
\hline Orde dua & Koefisien & -120.470 & 2.837 & 0.256 & 1.289 \\
& Galat baku & 0.0081 & $2.89 \times 10^{-4}$ & $1.45 \times 10^{-5}$ & $7.07 \times 10^{-5}$ \\
& Nilai-p & 0.000 & 0.000 & 0.000 & 0.000 \\
\hline Orde dua melalui satu & Koefisien & 16.610 & -0.012 & 0.0002 & -0.002 \\
& Galat baku & $2.18 \times 10^{-5}$ & $1.56 \times 10^{-6}$ & $7.39 \times 10^{-8}$ & $3.00 \times 10^{-7}$ \\
& Nilai-p & 0.000 & 0.000 & 0.000 & 0.000 \\
\hline
\end{tabular}

\subsection{Perbandingan Model SAR dan CAR}

AIC (Akaike's Information Criterion), penduga ragam dan nilai koefisien korelasi spasial merupakan kriteria yang biasa digunakan untuk melihat kebaikan suatu model spasial autoregresif SAR dan CAR. Uji kebaikan model CAR dengan orde dua melalui orde satu paling baik dibandingkan dengan model SAR orde satu, orde dua, orde dua melalui orde satu dan CAR orde satu dan orde dua dapat dilihat pada Tabel 4. Penentuan kebaikan model CAR ini dilihat dari nilai AIC dan penduga ragam yang sangat kecil.

Tabel 4: Analisis perbandingan kebaikan model pada SAR dan CAR untuk data penyakit Malaria di Provinsi Papua tahun 2013

\begin{tabular}{clllccc}
\hline \multirow{2}{*}{ Kriteria } & \multicolumn{3}{c}{ SAR } & \multicolumn{3}{c}{ CAR } \\
\cline { 2 - 7 } & Orde satu & Orde dua & $\begin{array}{l}\text { Orde dua } \\
\text { melalui } \\
\text { orde satu }\end{array}$ & Orde satu & Orde dua & $\begin{array}{l}\text { Orde dua } \\
\text { melalui } \\
\text { orde satu }\end{array}$ \\
\hline AIC & 196.430 & 195.83 & -13.466 & -260.750 & -230.280 & -449.130 \\
$\sigma^{2}$ & 69.963 & 66.871 & 0.022 & $2.39 \times 10^{-6}$ & $6.68 \times 10^{-6}$ & $1.22 \times 10^{-9}$ \\
$\hat{\rho}$ & 0.039 & 0.061 & -0.008 & 0.740 & 0.549 & 0.480 \\
\hline
\end{tabular}

\section{Kesimpulan}

Model CAR yang terbaik adalah orde dua melalui orde satu diibandingkan dengan model SAR dan CAR orde yang lain dalam penentuan faktor-faktor potensial yang mempengaruhi kejadian Malaria di Provinsi Papua pada tahun 2013. Dapat dilihat dari nilai AIC dan ragam yang paling kecil. Pada model CAR faktor-faktor yang signifikan pada orde satu, orde dua dan orde dua melalui orde satu yaitu rata-rata kecepatan angin bulanan $\left(X_{3}\right)$, rata-rata curah hujan bulanan $\left(X_{4}\right)$, dan pengobatan malaria dengan obat program pemerintah dengan mendapatkan obat ACT $\left(\left(X_{9}\right)\right.$. Namun model SAR dalam kasus ini tidak memberikan pengaruh spasial. 
Ucapan Terima Kasih. Terima kasih kepada Universitas Hasanuddin yang telah membantu membiayai penelitian ini melalui Hibah Internal Penelitian Dosen Pemula (PDPU) tahun anggaran 2020 dengan nomor kontrak 2649/UN4.1/KEP/2020.

\section{Daftar Pustaka}

Arsin, A. A. (2012). Malaria di Indonesia tinjauan aspek epidemiologi. Makassar (ID): Masagena.

[BPS] Badan Pusat Statistika. (2014). Provinsi Papua dalam angka 2014. Papua (ID): BPS Papua.

Cressie, N. (1990). Statistics for Spatial Data. New York (US): John Wiley \& Sons.

De Oliveira, V. (2012). Bayesian analysis of conditional autoregressive models. Annals of the Institute of Statistical Mathematics, 64(1): 107-133.

Febriyanti, R. D., \& Suwadi, J. F. (2019). Aktivitas Antimalaria Senyawa Tanaman Daun Kapur (Harmsiopanax aculeatus) terhadap Plasmodium sp. Jurnal Medula, 3(9): 465-471.

[KEMENKES RI] Kementerian Kesehatan Republik Indonesia. (2014). Profil Kesehatan Indonesia Tahun 2013. Jakarta (ID): Lembaga Penerbitan Badan Litbangkes.

[KEMENKES RI] Kementerian Kesehatan Republiklndonesia. (2013). Riset kesehatan dasar dalam angka (RISKESDAS 2013) Provinsi Papua. Jakarta (ID): Lembaga Penerbitan Badan Litbangkes.

Siswanto, Aidi, M. N., \& Djuraidah, A. (2017). Conditional Autoregressive (CAR) Modeling Uses Weighted Matrix to First and Second Order (Case Study: Malaria Disease in Papua Province). International Journal of Engineering and Management Research (IJEMR), 7(4): 297-301.

Wall, M. M. (2004). A close look at the spatial structure implied by the CAR and SAR models. Journal of Statistical Planning and Inference, 2(121): 311-324.

Waller, L. A. (2005). Applied Spatial Statistics for Public Health Data. New York (US): John Wiley \& Sons. 